\title{
ПРИЧИНИ БАГАТОЗНАЧНОСТІ В ЛІНГВІСТИЧНІЙ ТЕРМІНОЛОГІї
}

Ляшук Н. А. Причини багатозначності в лінгвістичній термінології.

У статті досліджено причини виникнення й функціонування явища багатозначності у системноструктурній та когнітивно-дискурсивній парадигмі. Виявлено, що явище багатозначності лінгвістичного терміна необхідно досліджувати у сфері його функціонування в науковому дискурсі.

Ключові слова: лінгвістичний термін, багатозначність, дискурс.

Ляшук Н. А. Причины многозначности в лингвистической терминологии.

В статье исследованы причины возникновения и функционирования явления многозначности в системно-структурной и когнитивно-дискурсивной парадигме. Выявлено, что явление многозначности лингвистического термина необходимо исследовать в сфере его функционирования в научном дискурсе.

Ключевые слова: лингвистический термин, многозначность, дискурс.

Lyashuk N. A. The causes of polisemantic features in linguistic terminology.

The article studies the causes and effects operation of polisemantic features of terminology in the system-structural and cognitive-discursive paradigm. It is revealed that the phenomenon of polisemantic features of linguistic term should be investigated in the sphere of its operation in scientific discourse.

Key words: linguistic term, polisemantic features, discourse.

Сучасна парадигма мовознавства, в основі якої лежать нові категорії, очевидно, може внести вклад у пояснення такого явища, як багатозначність терміна. Відомо, що з традиційної точки зору, термін $\epsilon$ однозначним, проте в дослідженнях останніх років мовознавці виявляють все більше фактів багатозначності терміна, тому проблема полісемії терміна $\epsilon$ досить актуальною. У межах сучасного термінознавства з'являються нові перспективи дослідження явища багатозначності терміна. Тому вважаємо за доцільне звернутися до розгляду терміносистеми 
мовознавства, у якому, на нашу думку, найвиразніше проявляються передумови виникнення явища багатозначності в термінології.

Сьогодні в українському термінознавстві досить помітним видається той факт, що наукових праць, присвячених вивченню лінгвістичної термінології набагато менше, ніж досліджень із технічних та природничих наук. Лінгвістична термінологія, за зауваженням О. Ахманової, досі «не $\epsilon$ раціонально організованою, семіотично бездоганною системою» [3, с. 509]. Лінгвісти, які знають краще за всіх, що таке термін, яка його природа, не можуть впоратися з хворобами власної термінології [15, с. 6].

Науковці відчувають гостру необхідність побудови чітких визначень термінів, створення струнких терміносистем, адже мовознавці зустрічаються 3 такими «недоліками, як омонімія, синонімія, концептуальна неоднорідність значення» [15, с. 31], полісемія термінів. Наприклад, такі терміни, як знак, інформація, текст, стиль, мова не мають загальноприйнятого розуміння, використовуються у різних значеннях, і це, звичайно, надто ускладнює наукове спілкування [9, с. 138]. Зазначені вище явища зумовлені розвиненим дублюванням терміноодиниць, схильністю вчених упроваджувати нові терміни без достатнього обгрунтування, дуже швидким розвитком лінгвістики в $\mathrm{XX}$ XXI столітті. Про наявність багатозначності в лінгвістичній термінології говорять багато дослідників (О. С. Ахманова, Б. М. Головін, В. М. Молодець, I. С. Кулікова, Д. В. Салміна) [2, с. 8; 8, с. 20-23; 21, с. 6-8; 15, с. 30-34]. Навіть аналіз лексикографічних джерел - лінгвістичних словників та енциклопедій - засвідчує, що явище багатозначності лінгвістичних термінів досить поширене в цій терміносистемі. Проте в українському мовознавстві досі немає праць, у яких би комплексно та всебічно досліджувалися причини явища багатозначності в лінгвістичній термінології, що й зумовлює актуальність нашого дослідження, адже саме багатозначність викликає труднощі в декодуванні термінів, що своєю чергою спричиняє узгодження їх змістової структури.

Методом суцільної вибірки було зібрано картотеку багатозначних лінгвістичних термінів, що нараховує понад 2000 терміноодиниць із лінгвістичних словників, зокрема 3 «Лінгвістичної енциклопедії» О. О. Селіванової (2010) - 111 одиниць, 3 «Енциклопедичного словникадовідника лінгвістичних термінів та понять» у 2-х т. за ред. О. М. Тихонова, P. I. Хашимова (2008) - 307 одиниць, 3 енциклопедії «Українська мова» (2000) - 67 одиниць, із «Словника лінгвістичних термінів» О. С. Ахманової (1966) - 465 одиниць, із «Словника-довідника лінгвістичних термінів» Д. Е. Розенталя, М. О. Теленкової (1985) - 105 одиниць, із словника «Український словотвір у термінах» (Л. О. Вакарюк, С. С. Панцьо, 2007) 71 одиниця та ін. Бачимо, що явище багатозначності досить поширене в лінгвістичній термінології, проте в наукових працях, присвячених проблемам термінології, є чимало поглядів щодо причин його формування. 
Що є причиною розвитку багатозначності в терміноодиницях, які за всіма вимогами повинні бути однозначними; які ознаки лінгвістичної термінології роблять це явище таким поширеним саме для терміносистеми мовознавства; як однозначний термін розширює своє семантичне наповнення та стає багатозначним?

Отже, мета статті - визначити основні передумови та причини розвитку явища багатозначності в лінгвістичній термінології.

Однозначність терміна i одновираженість поняття як ознаки термінологічної лексики мовознавці досліджували неодноразово, апелюючи до «ідеального терміна» [19, с. 7, 72-77]. Однак у термінологіях чітко однозначних відношень практично не має $[10$, с. $65-78 ; 13$, с. 123 ; 20 , с. $127 ; 24$, с. $4-13]$. Слова, що функціонують у ролі термінів, зберігаючи особливості, характерні для одиниць загальновживаної лексики, здебільшого не відповідають ідеальним вимогам, які ставлять науковці до терміноодиниць. Протиріччя між вимогою однозначності терміна та наявністю у нього кількох значень унаслідок термінологізації, розширення його семантики, очевидно, зумовлене асиметрією знака. Це явище вперше описано в працях С. Карцевського [12]. Концепція асиметрії, як зазначає, А. А. Уфімцева, базується на розумінні мовного знака як двосторонньої одиниці $[25$, с. 167]. Якщо ми допускаємо, що наука розвивається, вважає В. Г. Гак, то ми повинні визнати, що в термінів теж можуть розвиватися значення, і цей розвиток, тобто поява в терміна нових значень, призводить до виникнення багатозначності [7, с. 68-70].

Як і в будь-якій науці, в лінгвістиці існують основоположні наукові поняття, що формують $\dddot{11}$ термінологічну систему. В умовах неодноразової зміни мовної політики держави, змінювалася мета, зміст, методи, прийоми та засоби дослідження мовних явищ в українському мовознавстві, що відповідно спричиняло зміну значень методологічних термінів, що, на нашу думку, $\epsilon$ однією $з$ основних передумов розвитку багатозначності мовознавчих термінів. Крім того, відомо, що будь-яка наука з часом зазнає істотних змін, оскільки «наука - це певний процес, який розвивається в часі, це самоорганізована система, якою керують інформаційні потоки» $[22$, с. 11]. Українське мовознавство не $\epsilon$ винятком i 3 приходом незалежності України інтенсивно розвивається. Сучасна лінгвістика переживає новий етап свого розвитку. Зміна наукової парадигми спричинила зміни у визначенні основних лінгвістичних категорій, що своєю чергою, призвело до появи нових термінів i дефініцій, сформульованих на базі старих, що є однією з вагомих причин розвитку явища багатозначності лінгвістичної термінології. Отже, однією з причин виникнення багатозначності саме лінгвістичної термінології $\epsilon$ зміна наукової парадигми в мовознавстві.

Ще одним з найпоширеніших джерел багатозначності лінгвістичного терміна $\epsilon$ термінологізація, під час якої до загальномовного значення 
лексичної одиниці додається спеціальне, i сама лексична одиниця переходить в термінологію. Наприклад, мова, мовлення, слово, звук, ім'я, значення, зміст, говорити, розуміти, називати та ін., які звичайно, 3'явилися задовго до виникнення самої науки. Можна з упевненістю стверджувати, що всі вони мають високий рівень абстрагування. «Метамова мовознавства у більшості випадків будується на основі тих самих одиниць, що і мова-об'єкт, тобто має 3 нею єдину (тотожну) субстанцію <..>, як мова опису природної мови, метамова одночасно виступає і як частина природної мови» [4, с. 297].

Основним когнітивним механізмом, що лежить в основі появи у слова нових значень, є актуалізація імпліцитних компонентів когнітивної структури. Дослідити це явище можна лише в процесі функціонування терміна в науковому дискурсі, адже тільки так актуалізуються ознаки слова, не відображені в лексикографічній дефініції. Отже, явище багатозначності лінгвістичного терміна (так само як і будь-якого іншого терміна в гуманітаристиці) необхідно досліджувати лише у сфері його функціонування в науковому тексті.

Однозначний термін розвивається в дискурсі за рахунок постійного прирощення нового знання. Своєю чергою, нове знання формується у процесі розвитку професійної компетенції особистості, чи концептуалізації, у видах діяльності, які постійно ускладнюються [1, с. 7]. Отже, систематизуючи та впорядковуючи термінологію, потрібно розглядати терміносистему не окремо, а в контексті реального мовного слововживання як елемент метамови тієї чи іншої галузі знання, концептуальних взаємозв'язків термінів із загальновживаною мовою та «вивчення сполучуваності спеціальних термінів, особливо метафоричної сполучуваності, яка виявляє наукові інтуїції дослідника» [27, с. 14], тобто досліджувати явище багатозначності термінології необхідно не на етапі вже зафіксованих терміноодиниць у лексикографічних працях, а ще у процесі функціонування.

Дослідники когнітивно-дискурсивного напряму наголошують, що «ознаки, не відображені в лексичному значенні, не є суворо обов'язковими для сутностей певного класу, вони відображують різні конотації, асоціації, 3 якими предмет асоціюється у свідомості комунікантів» [26, с. 570]. Одним з основних когнітивних механізмів, який лежить в основі появи у слова нових значень, є актуалізація компонентів когнітивної структури, не зафіксованих у його первинному значенні, та тих, які залишилися «в підводній частині айсберга», на задньому плані. 3 другого боку, як наголошує О. С. Кубрякова, ономасіологічна та семантична структури слів не повні по суті, але слугують для представлення об'єкта в цілому, саме тому вони «відкриті» для поповнення їх новими семантичними ознаками в процесі розвитку знань про об’єкт. «Слово, відображаючи частину знань про об’єкт, - яку зазвичай і фіксують словники - здатне, якщо необхідно, 
вживатися в нових значеннях, відображати нове бачення об'єкта чи розташування його в новій структурі діяльності тощо» [14, с. 47-49].

Можна стверджувати, що явище багатозначності, концептуальної зокрема, властиве фактично кожному мовознавчому термінові, проте дослідити процес отримання терміном нових значень можна лише в процесі функціонування терміна. Для дослідження явища багатозначності важливим $є$ той факт, що кожен термін існує у двох сферах - фіксації та функціонування [16, с. 43]. Тобто, термін живе у двох вимірах: статичному та динамічному. Термін у статиці - це термін, зафіксований у словниках, довідниках, енциклопедіях. Терміни в динаміці- це терміни, що функціонують у текстах. У першому випадку, термін вільний від різних контекстуальних впливів, обмежений морфологічною формою, має чіткі дефініції, іншими словами, він не функціонує. У другому випадку, він динамічний, тому що реалізує закладену в усіх мовних одиницях властивість варіативності, не обмежений морфологічною формою, інколи конотує в контексті, завдяки чому здебільшого не вимагає чіткої дефініції, тобто він функціонує. Відомий термінолог А. В. Лємов наголошує, що кількість праць, у яких досліджено терміни в тому вигляді, як їх зафіксовано у словниках, набагато більше кількості досліджень, присвячених специфіці функціонування терміна в тексті [16, с. 33]. «Основну увагу надано терміну у сфері фіксації, а сфера функціонування нерідко вважається несуттєвою» [11, с. 61]. Але не враховувати сферу функціонування термінів не можливо, тому що це «найбільш природне вживання термінологіiі, це - те основне джерело, де з'являються нові терміни, де вони набувають обгрунтування та право на життя» [10, с. 41].

«Саме у процесі функціонування виникають типові ситуації, які порушують симетрію мовного знака-терміна (виникнення синонімів, розвиток полісемії, омонімії), саме тут наукові термінологічно-поняттєві системи еволюціонують, а іноді й революціонують» [16, с. 33]. Отже, окреслити систему понять певної науки, класифікувати, систематизувати термінологію можливо лише, досліджуючи терміни в природному для них середовищі, тобто в наукових текстах. У процесі функціонування наукового терміна проявляється діалектика відношень між елементами його системи. Кожен елемент може знаходитись у статиці чи змінюватись [16, с. 33-34]. Для нашого дослідження особливо важливо розглянути динаміку поняття того чи того терміна. Адже динамічний стан поняття передбачає «нестійкість його змістових ознак, можливість кваліфікувати денотат із різних точок зору, наявність полісемії терміна, нечіткість його змісту, різноплановість дефініцій. <..> У лінгвістичній термінології варіанти 3 динамікою поняття, в різноманітних комбінаціях зі станом експонента та денотата будуть переважати. Це пов'язано з тим, що наукове знання про сутність багатьох лінгвістичних реалій змінюється часто просто 
на очах, не говорячи вже про різноманітне трактування властивостей цих реалій, що й складає їх поняттєві характеристики» [Там само].

Аналіз семантики терміна можна здійснити, досліджуючи його як структурний елемент метамови наукової галузі. Незважаючи на те, що існує ширше розуміння терміна «функціонування», важливо розрізняти функціонування терміноодиниці в тексті та у сфері фіксації. Функціонування терміна в широкому сенсі розглядають як виконання ним своєї «особливої функції» [6, с. 8; 5, с. 16], що може бути пов'язано 3 визначенням наукової реалії, 3 iї ідентифікацією чи диференціацією, віднесенням терміна до певного ідіолекту, концепції (школи, напряму, епохи, методології), 3 можливістю вказівки на конкретну систему термінопонять, як спосіб використання терміна в тексті, принципи і методи його дефінування [17, с. 53]. Як бачимо, «функціонування терміна» - це також і «принципи і методи його дефінування», що входить до завдань лексикографії, яка займається описом семантичної структури одиниць мови під час укладання словників. Функціонування термінів у тексті і в лексикографічних джерелах важливо розмежовувати. Практика вивчення термінологічної лексики підказує необхідність «розумного» суміщення елементів як функціонального (текстоцентричного), так i лексикографічного (словоцентричного) методів, що дозволить представити повніший опис семантичної структури терміна: значення лексеми в словнику та іiі вживання в мові, текстах лінгвістичної тематики, що не завжди збігаються [28, с. 59]. У теорії мовних значень існує думка про принципову розбіжність значення у мові й мовленні, узуального й оказіонального значень [23; 18$]$.

Особливо складною є семантична структура багатозначних термінів, адже вона пов'язана 3 функціонуванням одного терміна-знака для найменування різних реалій; спостерігаємо оказіональне, індивідуальноавторське терміновживання, різну інтерпретацію терміна у словнику й тексті тощо, що й зумовлює виникнення явища концептуальної багатозначності в термінології. Лише термінологія у сфері функціонування відображає дійсний стан змістової організації наукових понять, що базується на певному світобаченні наукової спільноти або окремого вченого, становить суть його наукової концепції, що відбиває погляди певної лінгвістичної школи, певного напряму. А концепція, у свою чергу, може належати певній лінгвістичній школі, певному напряму чи навіть характеризувати точку зору одного вченого. I ця оригінальна, концептуальна точка зору на змістову організацію того чи того наукового терміна може відрізнятися від наукових концепцій інших учених-лінгвістів.

Основними причинами розвитку явища багатозначності в лінгвістичній термінології $є$ : 1) зміна наукової парадигми в мовознавстві, що зумовлює схильність вчених упроваджувати нові терміни без достатнього обгрунтування; 2) процес термінологізації, адже значна 
частина лінгвістичних термінів побудована на загальновживаній лексиці; 3) функціонування терміна, який постійно розвивається за рахунок постійного прирощення нового знання в дискурсі. Предметом нашого подальшого дослідження стануть механізми розвитку явища лексичної та концептуальної багатозначності лінгвістичних термінів.

\section{Література}

1. Алексеева Л. М. Медицинский дискурс : теоретические основы и принципы анализа / Л. М. Алексеева, С. Л. Мишланова. - Пермь : Изд-во Перм. ун-та, 2002. - 200 с.

2. Ахманова О. С. Словарь лингвистических терминов / О. С. Ахманова. - М. : Советская Энциклопедия, 1966. - $606 \mathrm{c.}$

3. Ахманова О. С. Терминология лингвистическая / О. С. Ахманова // ЛЭС. - М. : Сов. энциклопедия, 1990. -685 с.

4. Большой энциклопедический словарь : Языкознание / Гл. ред. В. Н. Ярцева. - 2-е изд. М. : Больш. росс. энц., 1998. -685 с.

5. Виноградов В.В. О теории художественной речи / В. В. Виноградов. - М. : Высшая школа, 1971. $-240 \mathrm{c}$.

6. Винокур Г. О. Избранные работы по русскому языку / Г. О. Винокур. - М. : Учпедгиз, 1959. -492 с.

7. Гак В. Г. Асимметрия лингвистического знака и некоторые общие проблемы терминологии / В. Г. Гак // Семиотические проблемы языка науки, терминологии и информатики. - М. : Изд-во Моск. унта., 1971, 4.1. - С. 68-70.

8. Головин Б. Н. Лингвистические термины и лингвистические идеи / Б. Н. Головин // Вопросы языкознания. - 1976 . - № 3. - С. 20-34.

9. Головин Б. Н. Лингвистические основы учения о терминах / Б. Н. Головин, Б. Ю. Кобрин. - М. : Высшая школа, 1987. - $104 \mathrm{c}$.

10. Даниленко В. П. Русская терминология / В. П. Даниленко. - М. : Наука, 1977. - 248 с.

11. Диброва К. Ю. Лингвистические термины как объект и предмет исследований / К. Ю. Диброва // Вестник Ленинградского ун-та. - 1986. - Вып. 4-6. - С. 58-62.

12. Карцевский С. Об асимметричном дуализме лингвистического знака / С. Карцевский // История языкознания XIX-XX веков в очерках и извлечениях. Ч. II. - М. : Прогресс, 1965. -С. 88-102.

13. Котелова Н. 3. К вопросу о специфике термина / Н. 3. Котелова // Лингвистические проблемы научно-технической терминологии. - М. : Наука, 1970. - С. 122-126.

14. Кубрякова Е. С. Части речи с когнитивной точки зрения / Е. С. Кубрякова. - М. : Институт языкознания РАН, 1997. -314 c.

15. Куликова И. С. Введение в металингвистику / И. С. Куликова, Д. В. Салмина. - СПб : «САГА», 2002. $-352 \mathrm{c}$.

16. Лемов А.В. Система, структура и функционирование научного термина (на материале русской лингвистической терминологии) / А. В. Лемов. - Саранск : Изд-во Мордов. ун-та, 2000. - 192 с.

17. Лемов А. В. Структура термина в процессе его функционирования / А. В. Лемов // Лингвистическая терминология в советском языкознании : Тезисы докл. - Н. Новгород, 1991. - С. 53-54.

18. Литвин Ф. А. Многозначность слова в языке и речи / Ф. А. Литвин. - М. : Высш. шк., 1984. -119 с.

19. Лотте Д. С. Вопросы заимствования и упорядочения иноязычных терминов и терминоэлементов. - М. : Наука, 1982. - 148 с.

20. Моисеев А. И. О языковой природе термина / А. И. Моисеев // Лингвистические проблемы научно-технической терминологии. - М. : Наука, 1970. - С. 127 - 138.

21. Молодец В. Н. Немецкие эквиваленты русских грамматических терминов : Учебное пособие / В. Н. Молодец. - Харьков : ХГУ, $1982-117$ с.

22. Налимов В. В., Мульченко 3. М. Наукометрия. Изучение развития науки как информационного процесса / В. В. Налимов, З. И. Мульченко. -М. : Наука, 1969. - 192 с.

23. Пауль Г. Принципы истории языка / Г. Пауль. - М. : Иностр. л-ра, 1960. 499 с.

24. Прохорова В. Н. Полисемия и лексико-семантический способ словообразования в современном русском языке. Лекции по спецкурсу / В. Н. Прохорова. -М. : Изд-во Моск. ун-та, 1980. - 88 с.

25. Уфимцева А. А. Знак языковой // Языкознание. Большой энциклопедический словарь / гл. ред. В.Н. Ярцева. - [2-е изд.]. - М. : Большая Российская энциклопедия, 1998. - С. 167.

26. Фурашова Н. В. О когнитивных механизмах развития многозначности слова / Н. В. Фурашова // Горизонты современной лингвистики : Традиции и новаторство : Сб. в честь Е. С. Кубряковой. - М. : Языки славянских культур, 2009. - С. 568-570.

27. Чернейко О. Язык исследователя как выражение его мировоззрения / О. Чернейко // Вестник Моск. ун-та. - Сер. 9. Филология. - 2009. - № 3. - С. 9-14.

28. Шурыгин Н. А. Семасиологический и лексикографический аспекты таксономизации лингвистических терминов и терминопонятий : дис. ... д-ра филол. наук : 10.02 .01 / Шурыгин Николай Александрович. - Тюмень, 2005. - 294 с. 